\title{
Generation and impacts of floating litter on urban canals and rivers: Rio de Janeiro megacity case study
}

\author{
B. Franz \& M. A. V. Freitas \\ Energy Planning Program and International Virtual Institute of Global \\ Changes - COPPE, Rio de Janeiro Federal University, Brazil
}

\begin{abstract}
In many developing countries, accelerated population growth, urban expansion in flood plain areas, increasing consumption (principally of disposable goods), inadequate solid waste collection and the lack of integrated water and environmental management policies lead to dumping of solid waste into canals and rivers and onto its banks, which correspond to the 'floating litter'. In Brazil, this occurs mainly in metropolitan regions, like in the megacity of Rio de Janeiro, located in the southeast of the country. The State Environmental Institute, in an attempt to limit the advance of floating litter in the coastal zones, installed barriers across the mouth of contributory rivers, labeled 'eco-barriers'. This institute promoted the removal in 2008 of about 150 tons of plastic, metal, wood and carton from the eco-barriers. The aim of the present study is to identify the impacts of the solid waste disposal into the rivers and canals and onto its banks where eco-barriers were installed, as well as to analyze the potential factors that contribute the entry of this waste into water bodies. The impacts and the factors were determined through the observation of river and canal banks at the end of 2009 and three eco-barriers in 2008. In addition, indicators were calculated. The increase of municipal Gross Domestic Product may play a greater role in the increase of public solid waste generation than in the increase of household solid waste generation. The floating litter fosters the propagation of vectors that transmit diseases, hampers the development of mangrove swamps (plastic suffocates seedlings), contaminates the water table, obstructs rainfall drainage ditches (favoring the occurrence of severe urban flooding) and attracts birds which pose hazards to airplanes.
\end{abstract}

Keywords: floating litter, water pollution, river basin management, megacity. 


\section{Introduction}

In developed world, 76 per cent of the population already lives in urban places, and people and jobs are moving out away from the big cities to smaller places. In the developing world, the cities have seen dizzy rates of growth during the last century, especially in its second half (Hall and Pfeiffer [1]).

Urban areas usually provide the economic resources to install water supply and sanitation but they also concentrate wastes (UNESCO [2]). The expanding urbanization in developing countries dramatically affects water resources in terms of quality (physical, chemical, biological pollution, etc.) and quantity (Ducrot et al. [3]). Adequate city water management is complex, because it requires the integrated management of water supplies for domestic and industrial needs, the control of pollution, the treatment of wastewater, the management of rainfall runoff (including storm water) and prevention of flooding, and the sustainable use of water resources. In addition, cooperation with other administrations that share the river basin or groundwater source (UNESCO [2]).

The population of Brazilian cities is estimated to have grown by 110 million in the past 60 years: $50 \%$ of the urban population is concentrated in 23 metropolitan areas (MMA/ANA/UNEP [4]). As in other developing countries, in Brazil a significant portion of this incoming population has been established in inappropriate areas, such as those originally set aside for environmental preservation and on steep hillsides or areas liable to flooding (Silveira [5]).

Most of Brazil's water resources are located in the Amazonas and Tocatins basins $(68 \%)$, inhabited by a mere $7 \%$ of the Brazilian population. In contrast, the Southeast (SE) home to $43 \%$ of the population and hold only $7 \%$ of its water resources (Carvalho and Magrini [6]). The Southern and SE regions of Brazil are the country's most economically developed areas. In these regions, rapid urbanization and industrialization has led to conflicts among different sectors competing for access to increasingly scarce and polluted water (Abers [7]).

Rapid urban expansion in Brazil from the mid twentieth century onwards coincided with a period of progressive deterioration in public finances, so that many pressing social needs, such as the demand for the solid waste collection and adequate sewage disposal, have gone largely unheeded (Geo Brasil [8]). At the same time, there has been considerable investment in channeling watercourses as a means of meeting the need for urban drainage. In many places, all or part of the sewage network is (unofficially) connected to rainwater drainage systems (storm sewers), with the result that sewage and storm water are mixed and deposited in watercourses and, ultimately (in coastal areas) into the sea. The combined result of this is that the drainage systems are also used for the disposal of household solid waste (Silveira [5]), mainly in areas where solid waste collection services and recycling policies are inefficient.

Once the solid waste enters the drainage system, there is a significant likelihood it will be carried by storm water conduits, water channels, streams, rivers and estuaries and eventually brought to the sea $[9,10]$, particularly during storms and other periods of high winds and high waves (USEPA [11]). Many items are highly buoyant and therefore capable of being transported many miles 
from their point of origin by winds or currents, endangering sensitive marine ecosystems and wildlife along the way $[9,11,12]$.

The city of Rio de Janeiro is the capital of the state of the same name, and the former capital of Brazil. It is located in the SE region of the country at the mouth of the Guanabara Bay. The urban area expanded to merge with other towns in this Bay area to form what is, nowadays, the Rio de Janeiro megacity (RJM), which has a current population of over 11,8 million inhabitants, according to the 2010 Census of the Brazilian Institute of Geography and Statistics - IBGE. This represents the greatest concentration of population on the Brazilian coast.

The lower courses of several rivers flowing into the Guanabara Bay have undergone modification, since the late 19th century/early 20th century as a result of drainage works undertaken by federal, state and municipal bodies (SEMADS/GTZ [13]) so as to enable the occupation of riparian areas. As a consequence, most of the sewage and a worryingly high proportion of the solid waste generated in the RJM are deposited into the bay directly or via approximately 35 watercourses that flow into it (PAC/PDBG [14]). The State Environmental Institute (INEA), in an attempt to limit the advance of floating litter in the Guanabara Bay and other coastal zones, installed barriers across the mouth of contributory rivers, labeled 'eco-barriers'.

The aim of the present study is to identify the impacts of the solid waste disposal into the rivers and canals and onto its banks where eco-barriers were installed, as well as to analyze the potential factors that contribute the entry of this waste into water bodies.

\section{Methodology}

The eco-barriers chosen for the monitoring of floating litter are shown in fig. 1 . Six campaigns were conducted between August and November 2008 whose aim was to observe the impact of floating litter accumulated by the eco-barriers. The eco-barriers installed in the Irajá and the São João de Meriti rivers (fig. 2) are floating structures built of wood, plastic barrels, PET (polyethylene terephthalate) bottles, recycled material and steel, anchored via steel cables on the river banks at around $50 \mathrm{~cm}$ above the water surface. At Arroio Fundo Canal, the River Water Treatment Plant's grid (fig. 3) is used as a barrier to retain floating litter.

The Irajá and the São João de Meriti rivers flow into the Guanabara Bay and their basins hold $17.4 \mathrm{~km}^{2}$ and $167.1 \mathrm{~km}^{2}$ of drainage area, respectively (PAC/PDBG [15]). The Guanabara Bay has a surface area of approximately 381 $\mathrm{km}^{2}$, with a north-south length of $28 \mathrm{~km}$ and a maximum east-west width of 27 km (fig. 1). The Arroio Fundo Canal flows into the Jacarepaguá Lagoon system and has a drainage area of $118 \mathrm{~km}^{2}$ (Ferreira and Cunha [16]). The basin of the Arroio Fundo Canal and Irajá River are located entirely within the municipality of Rio de Janeiro, whilst the basin of the São João de Meriti River lies, for the most part, in the municipality of Rio de Janeiro, but also flows through the municipalities of Duque de Caxias, São João de Meriti and Nilópolis (PAC/PDBG [15]), as is shown in fig. 1. 


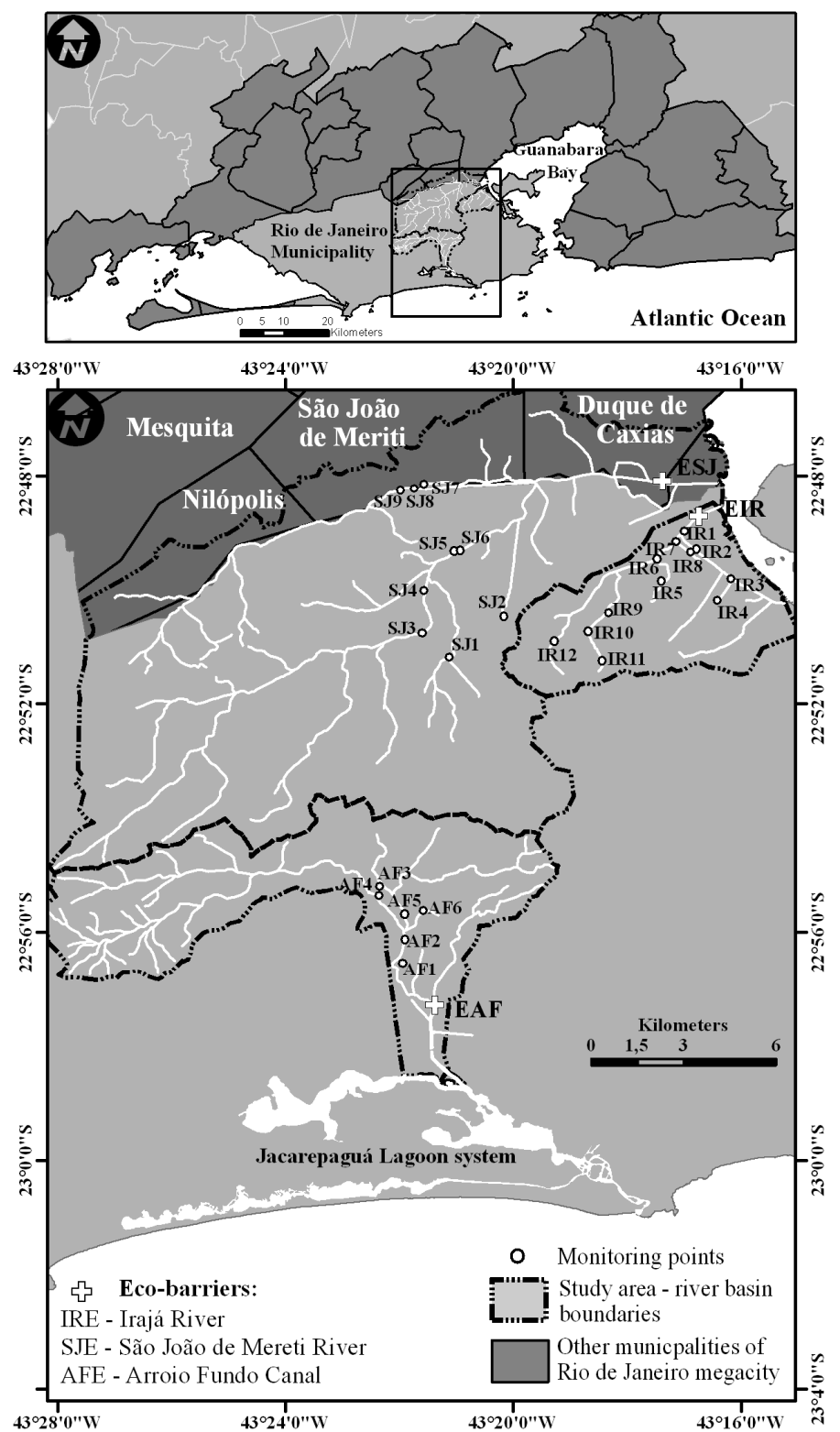

Figure 1: $\quad$ Localization of the study area and points monitored.

Part of the litter is collected by ecogaris (fig. 3), garbage collectors who collect the recycle material for sale. The remaining material is removed by equipment such as dredges and backhoes on rafts. In addition to the income generated from the sale of the material, each ecogari receives a fixed payment. 


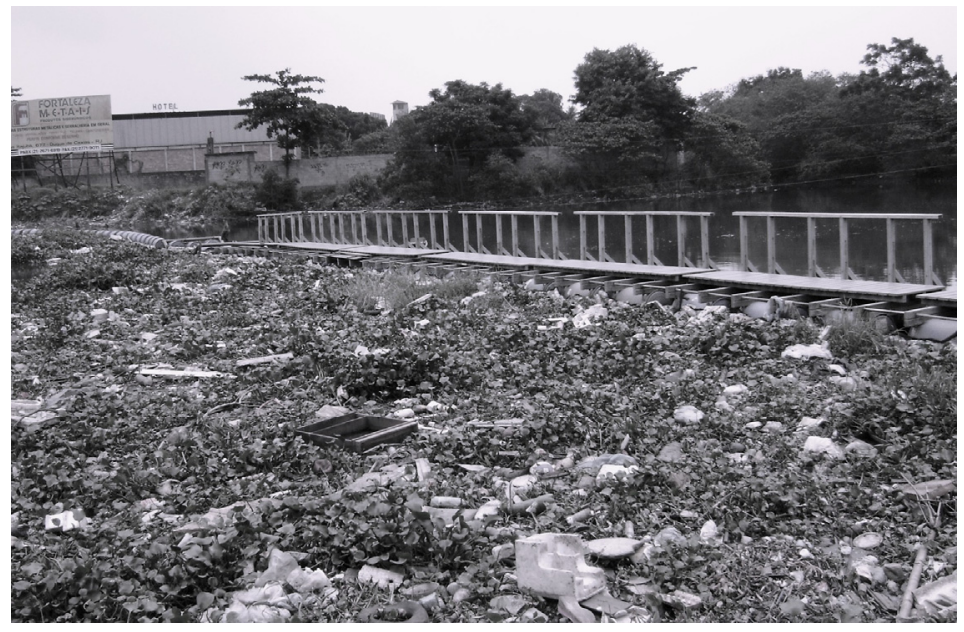

Figure 2: $\quad$ Structure of the eco-barrier at São João de Meriti River.

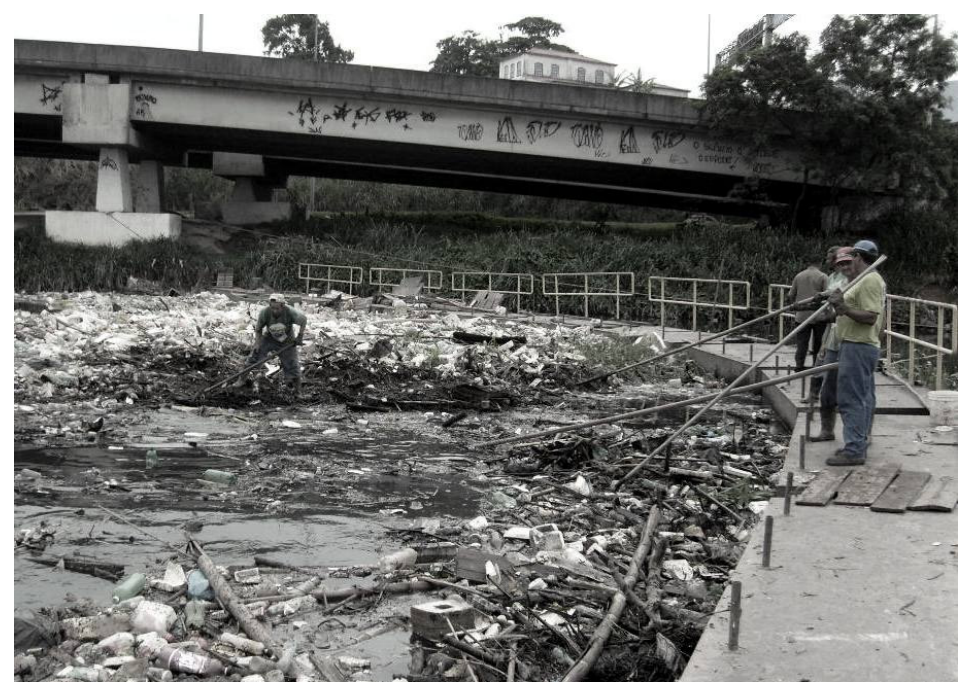

Figure 3: $\quad$ Structure of the eco-barrier at Arroio Fundo Canal.

The watershed of the lower Arroio Fundo Canal was subjected to dense occupation from the 1960s onwards, when it became home to a neighborhood built to re-house the former residents of demolished shanty towns in the wealthier areas of the city of Rio de Janeiro (Ferreira and Cunha [16]). Following this recent boom of urban growth in the surrounding areas, the lagoons that make up the Jacarepaguá Lagoon system are suffering from pollution problems similar to those of the Guanabara Bay (SEMADS/GTZ [13]).

Three campaigns were conducted to observe the river banks of watercourses within these basins between November and December 2009, whose aim was to 
verify contributing factors for the generation of floating litter, as well as its impacts. Observations could not be made in the surroundings of SJE (São João de Meriti eco-barrier) because this is an insecure area. The monitoring points (fig. 1) were photographed and its geographic positioning was obtained by means of a GPS.

The State Environmental Institute released the 2009 reports on the operation of the eco-barriers. The January 2009 report contains the quantitative data collected along the year 2008 and highlights that "the works on the operation of the eco-barriers have had their evaluation methods altered (INEA [17]), which was the justification presented for not having released the 2008 reports. The percentages of the materials collected by the ecogaris from the chosen ecobarriers in 2008 were calculated. The percentages of materials collected in 2009 were not calculated because the quantitative data collected from the eco-barriers are not presented separately from the quantitative data received at the 'ecopoints'. These are units installed close to the eco-barriers where recyclabe materials are received from inhabitants living in the surroundings and where all materials are subsequently separeted, weighed and pressed.

The following indicators were calculated for the analysis of the factors contributing to the generation of floating litter: GDP per capita, household solid waste per inhabitant and public solid waste per inhabitant.

\section{Impacts of floating litter on urban canals and rivers in the Rio de Janeiro megacity}

In 2008, the eco-barrier of São João de Meriti River (SJE) was the one from which the highest quantity floating litter was collected - a total of 40,213 kg, in comparison to the eco-barrier of the Irajá River (IRE) and the Arroio Fundo Canal (AFE), from which $23,744 \mathrm{~kg}$ and $34,355 \mathrm{~kg}$ of litter were collected, respectively.

Plastic was the predominant category of material collected in 2008 from SJE $(79.3 \%)$ and IRE $(52.2 \%)$ in relation to the total quantified (in $\mathrm{kg}$ ), as shown in table 1 .

Table 1: $\quad$ Percentages of materials collected from the eco-barriers.

\begin{tabular}{|c|c|c|c|c|c|}
\hline Eco-barrier & $\begin{array}{c}\text { Plastic } \\
(\%)\end{array}$ & $\begin{array}{c}\text { Wood } \\
(\%)\end{array}$ & $\begin{array}{c}\text { Aluminum } \\
(\%)\end{array}$ & $\begin{array}{c}\text { Iron } \\
(\%)\end{array}$ & $\begin{array}{c}\text { Carton } \\
(\%)\end{array}$ \\
\hline Irajá River & 52,2 & 34,9 & 2,5 & 6,2 & 4,2 \\
\hline $\begin{array}{c}\text { São João de } \\
\text { Meriti River }\end{array}$ & 79,3 & 13,1 & 1,0 & 6,5 & - \\
\hline $\begin{array}{c}\text { Arroio Fundo } \\
\text { Canal }\end{array}$ & 41,0 & 58,1 & - & 0,42 & 0,45 \\
\hline
\end{tabular}

Source of raw data: INEA [17]. 
As regards the total quantity of floating litter accumulated at the eco-barriers, the IRE is the one where the lowest quantity of accumulated litter was noted. Nevertheless, it should be highlighted that in the 6 (six) campaigns conducted, during the first 5 (five) of them the eco-barrier was partially broken, such that at times the floating litter simply headed on downstream towards Guanabara Bay. At SJE we noted in most of the campaigns a vast quantity of aquatic plants (water hyacinth - fig. 2), which is probably related to the greater quantity of sewage. In some parts of this eco-barrier, the material floated relatively freely whilst in others, items were tangled up with each other and with water hyacinth. The volume of water hyacinth and litter collected from this eco-barrier between January and March 2009 is shown in table 2.

Table 2: Period (2009) and volume (pails of $17 \mathrm{~m}^{3}$ ) of litter and water hyacinth collected by the dredge at the São João de Meriti River eco-barrier.

\begin{tabular}{|c|c|c|c|c|c|c|}
\hline $12-16 / 01$ & $19-23 / 01$ & $02-06 / 02$ & $09-13 / 02$ & $9-13 / 03$ & $16-20 / 03$ & $23-27 / 03$ \\
\hline 32 & 38 & 20 & 24 & 6 & 18 & 9 \\
\hline
\end{tabular}

Source: February, March and April 2009 reports (INEA [17]).

At AFE, the category wood was predominant $(58,1 \%)$. A large quantity of tyres was also found. The 2009 reports (INEA [17]) show that the quantity of tyres and large-scale waste is not decreased with the cleaning work developed upstream in the canal or the follow-up actions of environmental education. At this eco-barrier, the large quantity of floating litter, mainly of wood, formed an "artificial island" on which it was possible to walk (fig. 3).

By the SJE, IRE and AFE eco-barriers, there was a large quantity of supermarket plastic bags containing predominantly domestic waste, such as food packaging, cleaning products packaging, food leftovers and used toilet paper. The organic matter attracts flies and the presence of vermin could be observed. The garbage discarded directly onto the river banks or watercourses decreases the drainage capacity and causes pollution and bad odour, as well as being a factor that accelerates the proliferation of vectors such as rats, mosquitoes and flies (Pinto and Lobato [18]).

The animal carcasses found at SJE and IRE, in turn, attract vultures, which represents a danger to the safety of air traffic (SERLA/FGV [19]), considering that the Tom Jobim International Airport is not located far from these ecobarriers. Besides the litter found in the plastic bags, are also found near the IRE: cans of solvents (5L), cans of engine oil (20L), tetrafluoroethane cylinders, cans of soybean oil (18L), tyres, pieces of furniture (sofas, chests of drawers, beds, tables and chairs), mattresses, television sets, computer monitors, among others.

Carton packages (table 1) are also found in little representative percentages, probably due to the low consumption of products whose packaging is made of this material (INEA [17]). Iron and aluminium (table1) represent categories found in little representative percentages, which must be related to its economic value in the recycling market. In the RJM manhole covers and drain grates are 
stolen and sold as scrap iron. This favors the entrance of garbage in storm drains and thus they are easily clogged when heavy rains fall. Moreover, the problem constitutes a serious risk of accidents for the population. Through September of 2004, over 5 thousand such items were stolen, representing a loss of more than R \$ 1 million for city of Rio de Janeiro coffers, approximately \$350 thousand U.S. dollars at 2004 (SMO [20]).

In all points observed (fig.1), the watercourses were entirely modified, most of them having been completely channelled (either as an open-channel flow or a subterranean flow), a practice conducted in the city since the beginning of the 19 th century and which leads to the decrease in the drainage capacity.

A significant quantity of non-domestic waste was identified in some river banks, such as concrete debris (IR12, between IR3 and IR4, IR7 and IR8), wood (between IR7 and IR8, SJ2). a large quantity of dump and a car body were observed next to the point IR7. At IR3, rags were found inside a manhole. Scraps from oblations were observed between IR3 and IR4, IR12 and SJ7. A significant quantity of plastic was observed between IR3 and IR4, IR6 and IR7 and at the points IR2, IR12, SJ7 and SJ1. Garbage burning was also observed on the river banks between IR3 and IR4 and next to the points IR1, IR12, SJ2 and SJ9, as well as sewage disposal at the point AF5 and between IR7 and IR8, and AF1 and AF2. At IR3, rags were found inside a manhole. On the river banks and on the river bed at SJ5 there were concrete debris, fragments of plastic bags and two car bodies destroyed by fire. The canal at the points SJ3, SJ6, and between the points AF1 and AF2 is very silted up, a lot of garbage was observed on its bed as well as the growth of vegetation in the areas that were not flooded

\section{Factors contributing to the generation of floating litter in the study area}

The collection of the garbage produced in shanty towns is difficult due to the small number of trafficable ways and the narrowness of the alleys, which are factors that could also induce the practice of disposing of waste and all sorts of objects onto the hillsides and the channels of water drainage and sewage ditches.

At the points observed along the banks of the Irajá River (between IR 6 and IR7 - fig. 1) note was made of a significant quantity of garbage left there with a view to being picked up by the company of urban cleaning (such garbage was contained in plastic bags bearing the trademarks of commercial establishments). Nonetheless, the right thing to do is to place them in the "public places, near the service entrance of the buildings", as determined by Municipal Law on Urban Cleanliness. When this garbage is pawed at, sniffed and eaten by animals (including dogs, pigs and pigeons) or even garbage pickers who strew it around, this favours its falling into the canal, mainly during periods of downpours thus becoming floating litter.

Along the Penha Canal (between IR2 and IR3 - fig. 1), which corresponds to a less residential area, most of the garbage was strewn about (i.e. it was not put in plastic bags) along the banks or floating on the water. A huge quantity of mineral water and soft drink bottles (half liter PET type) indicating that they 
were probably generated from snacks and then incorrectly deposited on nearby sidewalks, on the banks or even tossed directly into the canal.

Inadequate practice in the city is an indication that it is necessary to strengthen policies related to educational campaigns on adequate garbage disposal and on recycling of such material.

A study conducted by Torres et al. [21] shows that, between 1995 and 2004, there was an increase in the accessibility to goods in RJM among the families with a household income per capita lower than half a minimum wage. Such study highlights higher rates of access to telephones and other domestic goods, such as washing machines and refrigerators and a decrease in the prices of apparel and durable goods. This situation can be explained, according to these authors, by the increase in the offer of consumer direct credit, a large growth in the consigned credit (including to retirees and pensioners), the higher rate of the population with access to bank accounts and the increase of microcredit. Probably the furniture, television sets and other large objects retained by the ecobarriers were discarded into the rivers after a purchase (which may have been facilitated by credit) to replace old objects.

The increase of the urban population is the most evident factor that influences the increase in solid waste generation. In the city of Rio de Janeiro the expenses per capita concerning the management of the urban solid waste show increasing trends, which may be related to the increase of garbage generated per inhabitant along these years, as shown by the trend line (in grey) of fig. 4, traced for household and public waste generation.

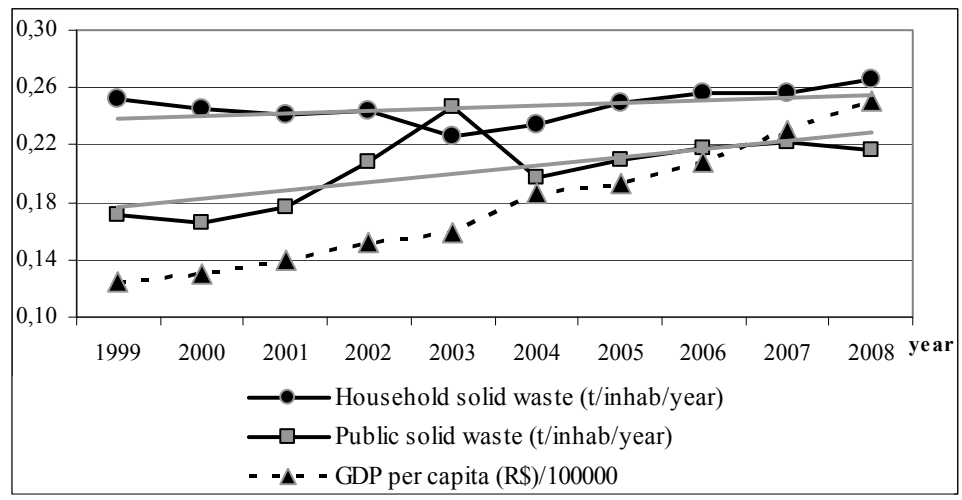

Figure 4: $\quad$ Solid waste generated per inhabitant and GDP per capita in the City of Rio de Janeiro (source: IPP [22]).

Higher household income tends to increase consumption In the city of Rio de Janeiro it can be verified that the increase in consumption (indicated by the series of data in fig. 4 related to GDP per capita in Brazilian reais/100,000) tends to influence more the increase of public waste than the increase of household waste. Since in the city temperature of the air is mild most of the year and the cariocas (Rio's inhabitants) usually engage in outdoor leisure activities, it is possible that 
the increase in their income has led to higher consumption in public areas, such as in bars that put tables on the sidewalks, street markets and special occasions (Christmas, mother's day, among others).

\section{The generation of floating litter in the Rio de Janeiro megacity in the context of water management}

During the 20th century the Brazilian federal authorities experimented with various models of water resource management, including centralized and decentralized systems, state or private administration, closed or open to foreign investment according to the political climate of the time. The 1988 Federal Constitution, which is still in force, was a turning point in terms of the redemocratization of the country after decades of military rule. It also established principles and guidelines that had a major impact on the management of water resources and environmental protection (MMA/ANA/UNEP [4]).

The current water resource management was established by the Law No 9,433/97 (inspired by the procedures adopted in France) that strives to administer this resource on the basis of the river basin concept, taken as the management unit. Furthermore, it introduced water basin planning committees into the Brazilian system.

Control over surface water is divided between federal and state domains (with waters which are completely within a single state under that state's control). Union and the states have their own water management legislation (Abers [7]). A single river basin may be shared by several state and municipal districts, giving rise to conflicts of interest over water use (Carvalho and Magrini [6]). Unlike other states, the State of Rio de Janeiro created a management unit based on the hydrographic region rather than a hydrographic basin.

In the State of Rio de Janeiro (RJ), State Law No 3239/1999 sets out the State Policy for Water Resources. Unlike other states, RJ created a management unit based on the hydrographic region rather than a hydrographic basin. Considering this aspect and the need for regulating Art.10 of State Law no 3239/99, RJ was divided into ten "Hydrographic Regions". Most of the territory of the Rio de Janeiro megacity lies within the Guanabara Bay Hydrographic Region, whose rivers are, due to intense urban concentration, more polluted than those of the neighboring Guandu Hydrographic Region, which provides most of the water supply to the Rio de Janeiro megacity.

The Guanabara Bay Hydrographic Region committee is composed of 60 members: Civil society occupies one third of the seats, representatives of the Federal, State and Municipal Governments another third, and water users of the region the final third. However, no companies of urban cleaning services is represented in this committee, which shows a serious gap in the integration of the water resources.

In February 2007, through an agreement signed by the State Government, Rio de Janeiro City Hall took over the management of sanitation of 21 neighborhoods in the municipality. The Municipal Secretariat for Public Works (SMO), through the Subsecretariat for the Management of River Basins (Rio- 
Águas), became, then, the agency in charge of the operation, expansion and improvement of the sanitary sewer services in these locations.

Considering that floating litter concerns the policies that guide the management of water resources, in the face of the overview here presented, it must be said that this issue must be approached in the context of river basins committees (considering the basins as a management unit).

In 2000, the Brazilian Congress approved the Law № 9,984, which it established the National Waters Agency (ANA). This agency is a Regulator with the specific purpose of controlling the use of waters in rivers and lakes falling within the Federal Government domain. The introduction of this Water Agency altered the initial format of the Brazilian management model grounded on the principle of decentralized water resource management, even in the river basins falling under Federal jurisdiction (Carvalho and Magrini [6]). The Rio de Janeiro state government retains control over issuing water use permits and a water resources council provides the basic rules for management. Thus, the basin committee depends on the government to invest in politics against water pollution.

\section{Conclusions}

The floating litter fosters the propagation of vectors that transmit diseases, hampers the development of mangrove swamps (plastic suffocates seedlings), contaminates the water table, obstructs rainfall drainage ditches (favoring the occurrence of severe urban flooding) and attracts birds which pose hazards to airplanes.

The factors that contribute to the litter floating generation in the Rio de Janeiro Megacity are: the easy access to the bank canals and rivers, the significant volume of solid waste generate in urban public areas, inefficient solid waste collection and mainly the lack successful educational campaigns to orient the population. The increase of the population and consumption is the reason of the increment on the total quantity of solid waste generation, as well as, the consequence of the large rise in number of the litter floating generation into the water courses.

In the context of the river basin management, policies to preventing solid waste pollution into an urban basin should be implemented with shared solutions between municipals and committee basin stakeholders.

\section{References}

[1] Hall, P. \& Pfeiffer U. Urban Future 21: Urban Future 21. A Global Agenda for 21st Century Cities. E\&FN Spon: London (English Version), pp. 5-43, 2000.

[2] United Nations Educational, Scientific, and Cultural Organization (UNESCO). Water for people water for life. Executive Summary for the World Water development report. UNESCO: Paris, pp. 15-16, 2003.

[3] Ducrot, R., Le Page, C., Bommel, P. \& Kuper, M. Articulating land and water dynamics with urbanization: an attempt to model natural resources 
management at the urban edge. Computers, Environment and Urban Systems, 28, pp. 85-106, 2004.

[4] MMA/ANA/UNEP. GEO Brasil: recursos hídricos. Executive Summary. Ministry of Environment; National Water Agency, United Nations Environment Programme. Brasília: MMA; ANA, 2007.

[5] Silveira, A. L. L. Problems of Urban drainage in developing countries. Proc of the Int. Conf.e on Innovative Technologies in Urban Storm Drainage. Novatech 2001, GRAYE 2001: Lyon, v.1., 143-150, 2001.

[6] Carvalho, R.C. \& Magrini, A. Conflicts over Water Resource Management in Brazil: A Case Study of Inter-Basin Transfers. Water Resources Management, 20, pp. 193-213, 2006.

[7] Abers, R.N. Organizing for Governance: Building Collaboration in Brazilian River Basins. World Development, 35 (8), pp. 1450-1463, 2007

[8] Geo Brasil. Perspectivas do Meio Ambiente no Brasil. Santos, T.C.C.; Câmara, J.B.D. (org). Edições IBAMA: Brasília, 2002.

[9] UNEP. Marine Litter, an analytical overview. Nairobi, Kenya, 2005.

[10] Armitage, N. \& Rooseboom, A., 2000. The Removal of Urban Litter from Storm-water Conduits and Streams: Paper1 - The quantities involved and catchment litter management options. Water SA 26 (2), pp. 181-187, 2000.

[11] U.S. Environmental Protection Agency. Assessing and Monitoring Floatable Debris. USEPA: Washington, 2002

[12] Sheavly, S.B., 2010. National Marine Debris Monitoring Program: Final Program Report, Data Analysis and Summary. Prepared for U.S. Environmental Protection Agency by Ocean Conservancy, 2007. 68 p.

[13] SEMADS/GTZ. Ambiente das Águas no Estado do Rio de Janeiro. BrazilGermany Technical Cooperation. Rio de Janeiro: SEMADS, 2001.

[14] PAC/PDBG. Qualidade de água da Baía de Guanabara (1990/1997). FEEMA: Rio de Janeiro, 1998.

[15] PAC/PDBG. Plano Diretor de Recursos Hidricos da Região Hidrográfica da Baía de Guanabara. Final Report - summary. Consórcio EcologusAgrar, Rio de Janeiro, 2005.

[16] Ferreira, F.P.M., Cunha, S.B., 1996. Enchente no Rio de Janeiro: efeitos da urbanização no Rio Grande (Arroio Fundo) - Jacarepaguá. Anuário do Instituto de Geociências - v. 19, 79-92.

[17] INEA, 2009 Rio ama os rios -Ecobarreiras. Reports from January to December 2009. Rio de Janeiro, State Environmental Institute.

[18] Pinto, F.A.O. \& Lobato, S.A.C. Programa Favela Limpa- Um exercício de cidadania. Proc of the $22^{\circ}$ Congresso Brasileiro de Engenharia Sanitária e Ambiental VI-185, 2003.

[19] SERLA/FGV, 2004 Relatório de Avaliação da Ecobarreira Piloto. Projeto Rio Ecobarreira Rio de Janeiro, 30 de novembro de 2004.

[20] SMO, 2010 Municipal Secretariat for Public Works. Online http://obras.rio.rj.gov.br/

[21] TORRES, H.G., BICHIR, R.M. \& CARPIM, T.P. Uma pobreza diferente? Novos Estudos, 74, p 17-22, 2006.

[22] IPP, 2011. Table 1488. Online http://www.armazemdedados.rio.rj.gov.br/>. 